\title{
SSEA-4 positive dental pulp stem cells from deciduous teeth and their induction to neural precursor cells
}

\author{
Ada Pricila Lopez-Lozano ${ }^{1,2}$ (D), Katiushka Arevalo-Niño ${ }^{1} \mathbb{B}$, Yolanda Gutierrez-Puente ${ }^{1} \mathbb{D}$, \\ Jose Luis Montiel-Hernandez ${ }^{3}$ (D), Victor Hugo Urrutia-Baca² ${ }^{2}$, Casiano Del Angel-Mosqueda ${ }^{4}$ (D) and \\ Myriam Angelica De la Garza-Ramos ${ }^{1,2,4,5^{*}}$ (D)
}

\begin{abstract}
Background: Stage-specific embryonic antigen-4 (SSEA-4) is a marker for the identification of multipotent embryonic cells. It is also positive in neuroepithelial cells, precursor neural cells (NPC), and human dental pulp cells. The aim of this study was to evaluate the potential morphodifferentiation and histodifferentiation to NPC of SSEA-4 positive stem cells from human exfoliated deciduous teeth (SHED).

Methods: A SHED population in culture, positive to SSEA-4, was obtained by magnetic cell separation. The cells were characterized by immunohistochemistry and flow cytometry. Subsequently, a neurosphere assay was performed in a medium supplemented with basic fibroblast growth factor (bFGF) and epidermal growth factor (EGF); afterward, cells were neurodifferenciated with a neurobasal medium. Finally, indirect immunohistochemistry was performed to identify neuronal markers.

Results: The morphological and histological changes in the SSEA-4 positive SHEDs were observed after induction with epidermal and fibroblast growth factors in neurobasal culture medium. At the end of induction, the markers Nestin, TuJ-1, and GFAP were identified.
\end{abstract}

Conclusions: The findings show that SSEA-4 positive SHEDs have a behavior similar to neuronal precursor cells. Our findings indicate that the dental pulp of deciduous teeth is a promising source for regeneration therapies associated with neurodegenerative diseases or peripheral nerve alterations.

Keywords: Dental pulp, Deciduous teeth, Neuroesphere assay, Neural differentiation, Neural precursor cells

\section{Introduction}

Neural precursor cells (NPC) in the nervous system (SN) can differentiate to neurons, astrocytes, and oligodendrocytes. In contrast to neural stem cells (NSC), NPC have limited self-renewal [1]. It was previously

\footnotetext{
* Correspondence: myriam.garzarm@uanl.edu.mx

${ }^{1}$ Facultad de Ciencias Biológicas, Instituto de Biotecnología, Universidad Autónoma de Nuevo León, Nuevo Leon, San Nicolas de los Garza, Mexico ${ }^{2} U n i d a d$ de Odontología Integral y Especialidades, Centro de Investigación y Desarrollo en Ciencias de la Salud, Universidad Autonoma de Nuevo Leon, Nuevo Leon, Monterrey, Mexico

Full list of author information is available at the end of the article
}

thought that this population of cells resided only in the human brain in development. Later, the presence of NPC was reported in the adult brain [1,2].

Degenerative diseases, traumatic events, and injuries that occur during or after medical procedures generate neuronal alterations, inflammation, cell death, and cytoarchitecture malformations in the central nervous system (CNS) and peripheral nervous system (PNS). Conventional medical therapies provide limited efficacy in the recovery of function after nerve damage. Because of nervous system maturation, and despite the presence

C The Author(s). 2022 Open Access This article is licensed under a Creative Commons Attribution 4.0 International License, which permits use, sharing, adaptation, distribution and reproduction in any medium or format, as long as you give appropriate credit to the original author(s) and the source, provide a link to the Creative Commons licence, and indicate if changes were made. The images or other third party material in this article are included in the article's Creative Commons licence, unless indicated otherwise in a credit line to the material. If material is not included in the article's Creative Commons licence and your intended use is not permitted by statutory regulation or exceeds the permitted use, you will need to obtain permission directly from the copyright holder. To view a copy of this licence, visit http://creativecommons.org/licenses/by/4.0/. The Creative Commons Public Domain Dedication waiver (http://creativecommons.org/publicdomain/zero/1.0/) applies to the data made available in this article, unless otherwise stated in a credit line to the data. 
of NPC, the ability to generate new neurons and glial cells is reduced and limited with increasing age [3].

Treatments based on mesenchymal stem cells (MSC) induce neuronal regeneration. These cells are located in bone marrow, adipose tissue, the umbilical cord, and the orofacial region [4]. MSC have been shown to have multiple neurotrophic and anti-inflammatory factors that favor nerve repair and serve as potentials candidates for cell therapy for CNS and SNP alterations.

The niches of MSC in the orofacial region are the dental pulp tissue of deciduous and permanent teeth, the dental follicle, the periodontal ligament, the oral mucosa, and the bichat fat pad $[5,6]$.

In pulp tissue, human dental pulp stem cells (DPSC) are MSC isolated from permanent teeth; stem cells from human exfoliated deciduous teeth (SHED) are in temporary teeth. Both cell populations come from cells in the groove of the neural plate in development; these are highly clonogenic and have multilineage differentiation, contributing to the equilibrium and specific conditions for tissue repair [7].

One of the relevant differences between DPSCs and SHED is that both cell populations can be obtained from individuals from different age groups, making them capable of expressing different gene types [8]. In particular, SHED, because of their origin and initial formation, can express embryo-stage genes such as stage-specific embryonic antigen-4 (SSEA-4), an antigen used to identify NPC $[9,10]$.

The objective of this study was to analyze the morphodifferentiation and histodifferentiation ability of a neural lineage of deciduous teeth mesenchymal cells obtained by magnetic separation with SSEA-4 antibody. We hypothesized that a cell population similar to NPC exists in human exfoliated deciduous teeth in the dental pulp.

\section{Materials and methods}

\section{Pulp tissue collection}

Pulp tissue was obtained from 40 deciduous teeth from children between 6 and 10 years of age. The included children were of both sexes with no clinical-pathological data and with healthy teeth in a state of exfoliation, candidates for extraction by therapeutic enucleation (germectomy), and orthodontic or orthopedic treatment. Children with any disease, less than 6 or greater than 10 years of age, with healthy teeth but no indication for extraction or with teeth with some pathology were excluded. The parents or guardians had to accept the participation of their child and sign a written informed consent. The Ethics Committee of the School of Dentistry of the Autonomous University of Nuevo Leon evaluated and approved the protocol.

\section{Dental extraction}

The study was performed with a total of 40 teeth with one exclusive assay for each patient sample. The indications given to each participant (patient or parentguardian) were to perform dental prophylaxis at the dental office one week before obtaining the sample, tooth brushing daily, 3 times a day, and a diet low in carbohydrates. On the day of sample collection, second prophylaxis and direct cleansing of the tooth surface for $5 \mathrm{~min}$ with gauze soaked in $2 \%$ chlorhexidine (Consepsis-Ultradent) were performed. The dental samples obtained were transported to the laboratory in $50 \mathrm{ml}$ Falcon tubes (Corning) with $1 \mathrm{X}$ phosphate-buffered saline (PBS), $100 \mu \mathrm{g} / \mathrm{mL}$ streptomycin, $100 \mathrm{U} / \mathrm{mL}$ penicillin, and $0.25 \mathrm{mg} / \mathrm{mL}$ amphotericin B (Sigma).

\section{Dental pulp extraction}

Odontosection of the extracted dental samples was performed at the level of the cementoenamel junction (limits of the crown and the dental root) with a medium diamond grain disk (NTI), mounted on a low-speed electric micromotor (Dremel) with constant irrigation with $0.9 \%$ sterile saline solution (PISA). In samples with an open radicular apex, this was used as an access to remove the pulp tissue with no.20 Triple Flex endodontic extractors and files (Kerr).

Subsequently, the extracted tissue pulp was placed in 2 $\mathrm{mL}$ Eppendorf tubes with $1 \mathrm{~mL} 1 \mathrm{X}$ PBS, $100 \mu \mathrm{g} / \mathrm{mL}$ streptomycin, $100 \mathrm{U} / \mathrm{ml}$ penicillin, and $0.25 \mathrm{mg} / \mathrm{mL}$ amphotericin B (Sigma) and preserved in refrigeration at $4{ }^{\circ} \mathrm{C}$ without exceeding $48 \mathrm{~h}$ after the extraction.

\section{Tissue dissociation}

The tissue pulp was dissociated in a GentleMACS ${ }^{\mathrm{Tm}}$ dissociator in a $\mathrm{C}$ tube (Miltenyi Biotec) with $4.7 \mathrm{~mL} 1 \mathrm{X}$ PBS. After dissociation, the sample was centrifuged at 300x g for $10 \mathrm{~min}$.

After obtaining the cell pellet, $3 \mathrm{mg} / \mathrm{mL}$ of collagenase type I (Sigma) and $4 \mathrm{mg} / \mathrm{ml}$ of dispase (Sigma) were added. The suspension was then incubated for $30 \mathrm{~min}$ at $37{ }^{\circ} \mathrm{C}$. After incubation, the suspension was centrifuged again at 300x g for $10 \mathrm{~min}$. Subsequently, the supernatant was removed and the enzymes inactivated by washing with $5 \mathrm{~mL}$ DMEM F12 medium (Gibco) and $10 \%$ fetal bovine serum (FBS) (Gibco). The suspension was filtered with an $80 \mu \mathrm{m}$ membrane (Millipore); finally, it was resuspended in $1 \mathrm{~mL}$ culture medium.

\section{Cell count}

A hemacytometer or Neubauer chamber (Marienfeld) was used to determine the number of cells and their viability. An aliquot of $10 \mu \mathrm{l}$ of the cell suspension and $10 \mu \mathrm{l}$ of trypan blue $0.05 \%$ (Sigma) was obtained with a micropipette (Eppendorf) before homogenization; the 
$20 \mu \mathrm{l}$ were mixed in a $2 \mathrm{ml}$ Eppendorf tube and placed in Neubauer chamber for cell counting.

\section{Cell culture}

Dulbecco's Modified Eagle's Medium/Nutrient Mixture F12 Ham (DMEM-F12), 10\% FBS (Gibco), $100 \mathrm{mg} / \mathrm{mL}$ streptomycin, $100 \mathrm{U} / \mathrm{ml}$ penicillin, and $0.25 \mu \mathrm{g} / \mathrm{ml}$ amphotericin B (Sigma) were used for the primary cell culture (PCC). The counted cell suspension was resuspended in $5 \mathrm{~mL}$ of culture medium and placed in 25 $\mathrm{cm}^{2}$ Falcon vials (Corning) for cell culture.

The PCC was kept in a chamber with $5 \% \mathrm{CO}_{2}$ at $37{ }^{\circ} \mathrm{C}$ (Thermo Scientific). After $72 \mathrm{~h}$, the non-adherent cells were removed; the culture medium was changed every 3 days. Subsequently, the culture medium was removed, and the cells adhered to the culture flask were washed three times with $1 \mathrm{X}$ PBS. Then, cell trypsinization was performed with $0.25 \%$ trypsin and $1 \mathrm{mM}$ EDTA (Fisher Scientific). Trypsin/EDTA was added, and the solution was incubated for $5 \mathrm{~min}$ at $37{ }^{\circ} \mathrm{C}$ in a chamber with $5 \%$ $\mathrm{CO}_{2}$. After incubation, the enzyme was inactivated with the culture medium in a proportion equal to the volume of the content in the flask; it was then centrifuged at $300 \mathrm{x}$ g for $10 \mathrm{~min}$. The cells were resuspended in the culture medium and centrifuged; later, they were resuspended in $1 \mathrm{X}$ PBS with $1 \%$ bovine serum albumin (BSA) (Sigma-Aldrich). Magnetic microbeads of $50 \mathrm{~nm}$ conjugated with SSEA-4 antibody (MACS/Miltenyi Biotec) were incubated with the cell suspension for $15 \mathrm{~min}$ at $4{ }^{\circ} \mathrm{C}$ to achieve stage 3 cell growth and expansion. The separation of mesenchymal stem cells derived from the dental pulp was performed using a MACS magnetic separator system (Miltenyi Biotec). Finally, the content of the $15 \mathrm{~mL}$ tubes (Corning) was collected to recover the SSEA-4 antibody-positive fractions.

\section{Flow cytometry staining}

Staining for flow cytometry was performed with the antibodies CD45 FITC, CD14 PE (present in hematopoietic stem cells), CD13 PE, CD44 FITC, and CD105 PE (present in mesenchymal stem cells) to identify and

Table 1 Monoclonal antibodies used for identification of mesenchymal cell membrane markers

\begin{tabular}{lll}
\hline Origin & Antigen & Manufacturer \\
\hline Mouse & CD44 FITC & Miltenyi Biotec \\
Mouse & CD71 FITC & Miltenyi Biotec \\
Mouse & CD90 FITC & Miltenyi Biotec \\
Mouse & CD146 FITC & Miltenyi Biotec \\
Mouse & CD13 PE & Miltenyi Biotec \\
Mouse & CD105 PE & Miltenyi Biotec \\
\hline
\end{tabular}

FITC fluorescein-5-isothiocyanate, $P E$ phycoerythrin study the cell population in the SSEA-4 positive fraction (Table 1).

\section{Direct immunocytochemistry}

Immunohistochemistry was performed with primary antibodies to identify mesenchymal cell markers. These cells were seeded in 16-well chamber slides for cell culture (Nunc $^{\mathrm{Tm}}$ Lab-Tek). The culture medium was removed when the cells reached a confluence of $80 \%$ inside each well. The cells were washed with $1 \mathrm{X}$ PBS and placed in methanol at $-2{ }^{\circ} \mathrm{C}$ for $10 \mathrm{~min}$ to fix the cells. Afterward, they were incubated at environmental temperature with $1 \mathrm{X}$ PBS and 2\% BSA for $30 \mathrm{~min}$. After $30 \mathrm{~min}$, the antibodies for identification were added, and the cells were incubated for $3 \mathrm{~h}$ at environmental temperature and in darkness.

At the end of the incubation time, the supernatant was removed, and 3 washes were performed with $1 \mathrm{X}$ PBS. To identify nucleic acids, 1:1000 DAPI (SigmaAldrich) was added; the cells were incubated for $15 \mathrm{~min}$ in darkness, and one wash was performed with 1X PBS.

After staining, the structures in the slide chambers were removed, $10 \mu \mathrm{l}$ of mounting solution (Dabco) was added, and a coverslip was placed on each field for analysis. The coverslips were sealed to the slide with enamel, and the slides were analyzed with an inverted fluorescence microscope (Zeiss Z1, Carl Zeiss, USA).

\section{Neuronal differentiation culture}

The neuronal differentiation protocol was divided into two stages with different culture media: Neuronal A medium (NA) (neurosphere assay) pre-induction to maintain multipotentiality, growth, and division of neurospheres from SHED; and neuronal B medium (NB), directed at cell differentiation.

\section{Neuronal A medium (neurosphere assay)}

The components of the pre-induction medium were DMEM-F12 (Gibco), $50 \mu \mathrm{l} / \mathrm{mL}$ Supplement (Gibco), 2\% FBS (Gibco), $3 \mu \mathrm{l} / \mathrm{mL}$ L-glutamine (Gibco), $20 \mathrm{ng} / \mathrm{mL}$ epidermal growth factor (EGF), $20 \mathrm{ng} / \mathrm{mL}$ fibroblast growth factor (FGF), $100 \mu \mathrm{l} / \mathrm{mL}$ streptomycin, $100 \mathrm{U} / \mathrm{mL}$ penicillin, and $0.25 \mathrm{mg} / \mathrm{mL}$ amphotericin B (Sigma-Aldrich). The cells previously separated by magnetic microbeads conjugated with SSEA-4 antibody were placed in a $25 \mathrm{~cm}^{2}$ culture vial (Corning) for expansion. After performing the second cell passage, the cells were trypsinized and reseeded in $5 \mathrm{~mL} \mathrm{NA}$ to await neurosphere formation in the pre-induction stage for 7 days; half of the medium was changed every 3 days. 


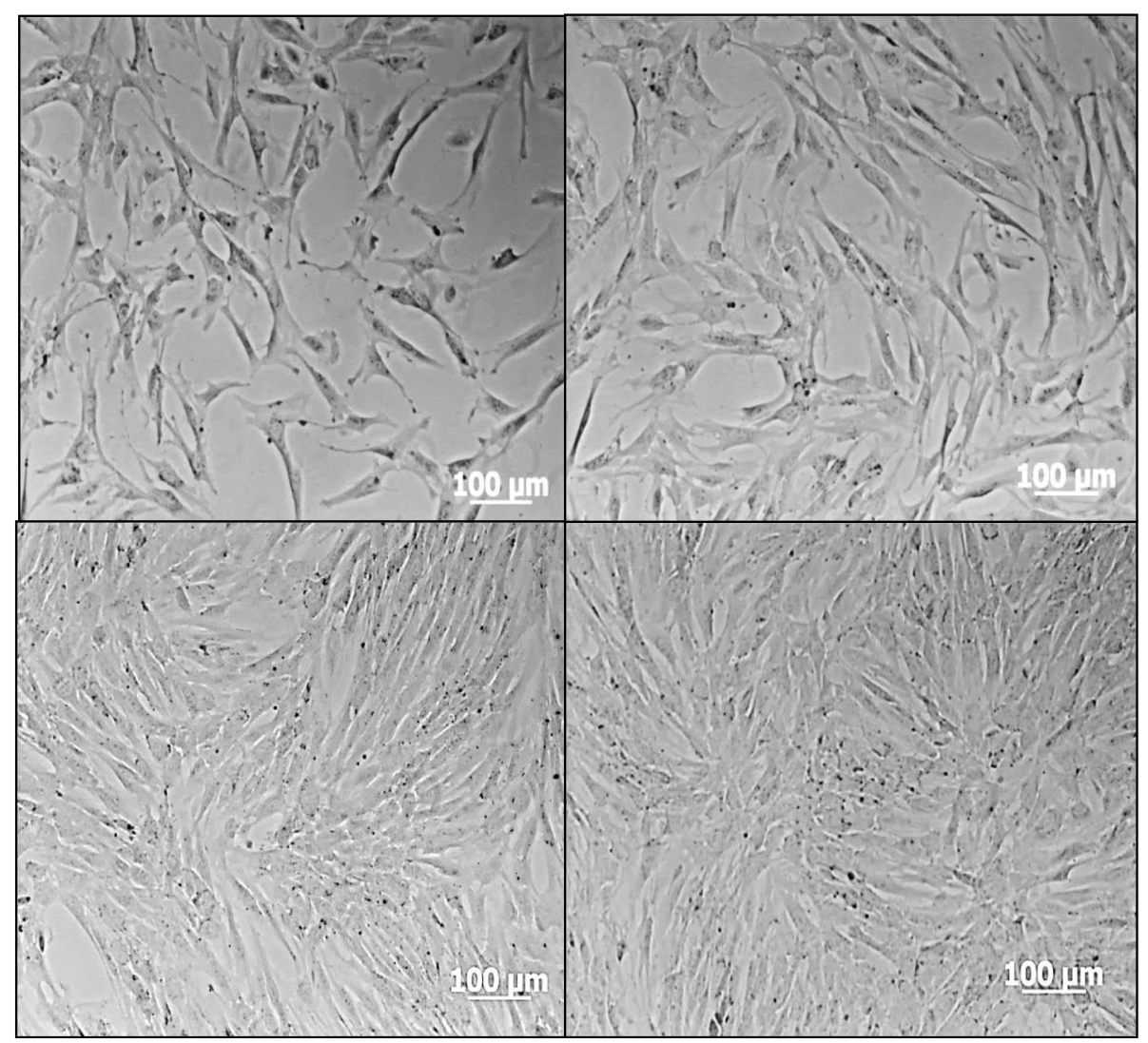

Fig. 1 Microphotographs obtained with a phase contrast microscope. Initial culture - Step 0 (PO) dental pulp cells from deciduous teeth in growth medium. A 50\% confluence, (B) 60\% confluence, (C) 70\% confluence, (D) $80 \%$ confluence

\section{Neural medium $B$}

The components of the cell differentiation medium were half Neurobasal (Gibco), $70 \mu \mathrm{l} / \mathrm{mL}$ of supplement B27, $3 \mu \mathrm{l} / \mathrm{mL}$ L-glutamine (Gibco), $500 \mathrm{nM}$ retinoic acid (Sigma Aldrich), $100 \mu \mathrm{g} / \mathrm{mL}$ streptomycin, $100 \mathrm{U} / \mathrm{mL}$ penicillin, and $0.25 \mathrm{mg} / \mathrm{mL}$ amphotericin B (Sigma-Aldrich). The cells were kept in NB for 7 days; half of the medium was changed every 3 days.

The cells were seeded on slides with two-well chambers for cell culture (Nunc ${ }^{\text {Th }}$ LabTek). For cell adhesion, the surface of the slide was prepared with $0.1 \mathrm{mg} / \mathrm{mL}$ of Poly-L-Lysine (Sigma-Aldrich). A total of $60 \mu \mathrm{l}$ was added to each well and kept in incubation for $12 \mathrm{~h}$ at $37{ }^{\circ} \mathrm{C}$. Later, the supernatant was removed, and each well was washed with $500 \mathrm{~mL}$ milli-Q (mQ) double distilled water. The cells were seeded in $400 \mu \mathrm{l} \mathrm{NB}$ and kept in culture for 7 days; half of the medium was changed every 3days.

\section{Indirect immunohistochemistry}

After seven days in NB, indirect immunohistochemistry was performed to identify neuronal markers using secondary antibodies for Nestin, B-III Tubulin (TuJ-1), and glial fibrillary acidic protein (GFAP).
After the culture plates were observed in a phasecontrast microscope, the NB medium was removed, and the cells were washed with $400 \mu \mathrm{l} 1 \mathrm{X}$ PBS. The cells were fixed with methanol at $-2{ }^{\circ} \mathrm{C}$ for $10 \mathrm{~min}$; the supernatant was removed, and 2 washes were performed with $1 \mathrm{X}$ PBS.

The cell membrane was permeabilized with $0.5 \%$ Triton X-100, and the cells were incubated for $5 \mathrm{~min}$. After incubation, 3 washes of 5 min with $1 \mathrm{X}$ PBS were performed; then, a blocking solution was added (10\% fetal goat serum [FGS] in 1X PBS). The cells were then incubated for one hour at environmental temperature to avoid unspecific reactions.

For antibody dilution-titration, 1\% FGS with $1 \mathrm{X}$ PBS was prepared, adding the primary antibodies (mouse-anti-human), anti-Nestin, anti-B-III tubulin, and anti-GFAP. The solution was incubated for $12 \mathrm{~h}$ (during the night) at $4{ }^{\circ} \mathrm{C}$. The supernatant was removed the next day, and 3 washes of 5 min with $1 \mathrm{X}$ PBS were performed. Subsequently, the secondary antibodies anti-Nestin, anti-B-III tubulin, and antiGFAP (antibodies conjugated with Alexa Fluor 568) (rabbit-anti-mouse) were added. This solution was incubated for one hour at environmental temperature 

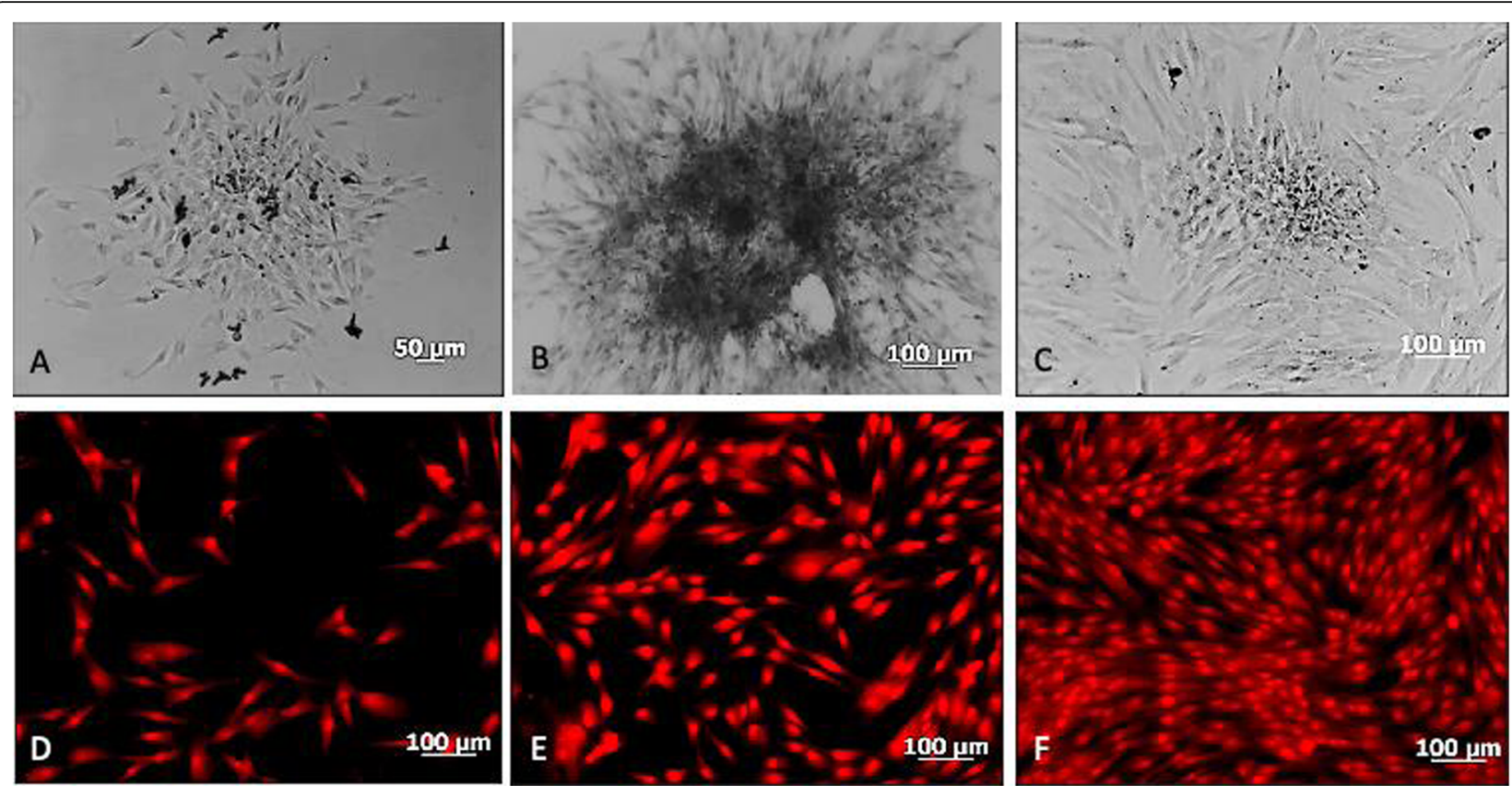

Fig. 2 Mesenchymal cell culture from deciduous dental pulp, positive for the SSEA-4 antibody. A, B, C: Microphotographs obtained with a phase contrast microscope on days 3, 5, and 7 of culture in growth medium showing the cell organization and growth in colony forming units (CFUs). D, E, F, Microphotographs obtained with an inverted fluorescence microscope where an autofluorescence assay with formalin is shown on days 3, 5, and 7, of culture in growth that shows the growth pattern in CFUs and homogeneous cell morphology

and in the dark. After incubation, 3 washes of $5 \mathrm{~min}$ with 1X PBS were performed.

For cell nucleus staining, 1:1000 DAPI (Sigma-Aldrich) was added, and the cells were left to incubate for $10 \mathrm{~min}$ in the dark. After removing DAPI, one wash with $1 \mathrm{X}$ PBS was performed.

After staining with primary and secondary antibodies, the structure of the chambers of the slides was removed, $10 \mu \mathrm{l}$ of mounting solution (Dabco) was added, and a coverslip was placed in each field for analysis. The mounting solution drained through the coverslip for $24 \mathrm{~h}$ to remove the excess; eventually, the coverslip was sealed with enamel, and the analysis was performed with an inverted fluorescence microscope (Zeiss Z1, Carl Zeiss, USA).

\section{Results}

\section{Obtention of biological samples from teeth}

The teeth were from dental enucleations (permanent premolar germ extractions before normal eruption), teeth exfoliation, and serially extracted teeth. The majority were male patients; the age range was 8 to 9 years. The number of cells obtained per sample was variable, but a mean of 50,000 viable cells was considered.

The replication time of the human dental pulp cells was $21.89 \mathrm{~h}$. The cells adhering to the culture vial had a heterogeneous appearance in shape and size, a fusiform morphology with some relatively short and wide or rather long, thin, and very branched cytoplasmic extensions, oval nuclei, and scarce cytoplasm. They showed fast growth, reaching $80 \%$ confluence by day 10 and $100 \%$ by day 14 . Three cell passages were performed, and in each, the expansion rate increased (Fig. 1).

\section{Isolation and characterization of SHED}

The mesenchymal cells positive to magnetic microbead separation conjugated with the SSEA-4 antibody were adherent to the culture vial, had a homogeneous morphology in size, and a spindle shape, an oval nucleus, scarce cytoplasm, a growth characteristic in colonies or colony-forming units (CFUs) (approximately 100 cells per CFU) and a high expansion rate, similarly to the not purified culture (Fig. 2).

Flow cytometry identified the immunophenotype of the cell population isolated with magnetic microbeads and SSEA-4 antibody. The cell population characterization by immunocytochemistry was positive for the mesenchymal cell membrane markers CD44, CD71, C13, and CD105, and negative for the hematopoietic antibodies CD45 FITC, CD14 PE. Characterization of the cell population with direct immunocytochemistry was positive for mesenchymal cell membrane markers (Fig. 3; Table 2). 


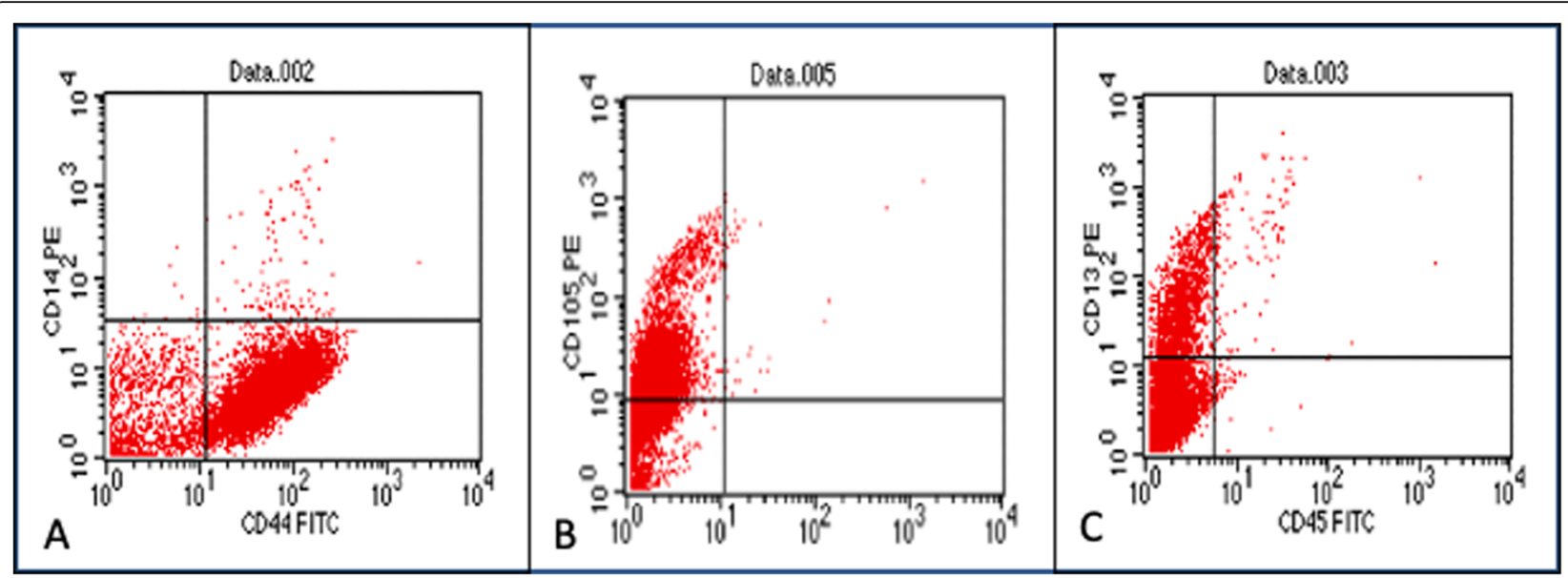

Fig. 3 Dot plots obtained with a flow cytometer. A CD14 (-), CD44 (+) homogeneous cell population; (B) CD105 (+) homogeneous cell population; (C) CD13 (+), CD45 (-), homogeneous cell population

\section{Neural differentiation}

The cells in neuronal A medium initially presented as a monolayer adherent to the culture vial with a fibroblastic morphology organized in CFUs. In the next 48 to 72 hours, an increase in the cell density of each CFU was observed. The cells gradually changed their morphologies, longitudinally compacting the colony. By the third day, an accumulation of cells losing adhesion to the surface of the culture vial was observed, forming bodies with a spheroid shape and a mesenchymal cell structure. The spheroid bodies or neurospheres kept developing and growing in the pre-induction medium until the tenth day (Fig. 4).
The cells derived from the neurospheres, seeded on a surface treated with Poly-L-lysine and in neuronal B medium, presented radical morphological modifications, starting with a mean size of 20$50 \mu \mathrm{m}$ (Fig. 5). In differentiation culture induced with retinoic acid, they increased in length by more than $50 \%$ by issuing multiple extensions with condensed well-defined and apparent nuclei, a cell body or soma showing scarce cytoplasm and granules in its interior. Cell density considerably decreased by inducing a neuronal differentiation of more than $70 \%$.
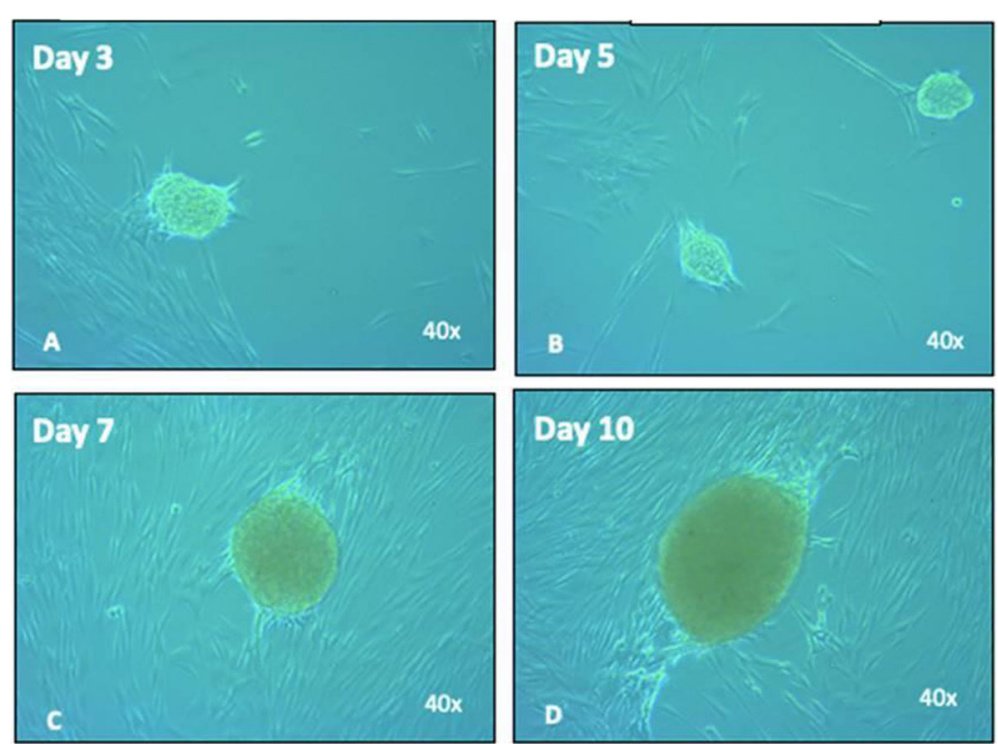

Fig. 4 Neurosphere development in neuronal medium A. A Neurosphere formation was observed from the third day; appearance of a structure with a condensed center, a perimeter halo, and development in suspension (non-adherent). B On day 5, an increase in the number of neurospheres was observed. C From the seventh day, the beginning an increase in the size of the neurospheres was observed. D Cells in continuous division increasing the dimensions of the spheroid structure in suspension 
Table 2 Stem cells from human exfoliated deciduous teeth (SHED) immunophenotype

\begin{tabular}{lll}
\hline Membrane marker & Expression & Immunophenotype \\
\hline CD44 FITC & $(+)$ & MSC \\
CD105 PE & $(+)$ & MSC \\
CD13 PE & $(+)$ & MSC \\
CD14 PE & $(-)$ & HSC \\
CD45 FITC & $(-)$ & HSC \\
\hline
\end{tabular}

FITC fluorescein-5-isothiocyanate, PE phycoerythrin, MSC mesenchymal stem cells, HSC hematopoietic stem cells

\section{Identification of neuronal markers}

The immunocytochemistry assay after induction with NB for 10 days was positive for the marker nestin, present in neuroepithelium or precursor neural cells; BIII Tubulin (TuJ-1), positive for neuronal activity and related with neurogenesis and axonal growth; and glial fibrillar acid protein (GFAP), present in the intermediate filaments of the cytoskeleton, mainly in glial cells (Figs. 6 and 7).

\section{Discussion}

The dental pulp is a specialized tissue generated from ectomesenchyme formed by the ectoderm of neuroepithelial and mesoderm cells rich in different cell populations $[11,12]$.
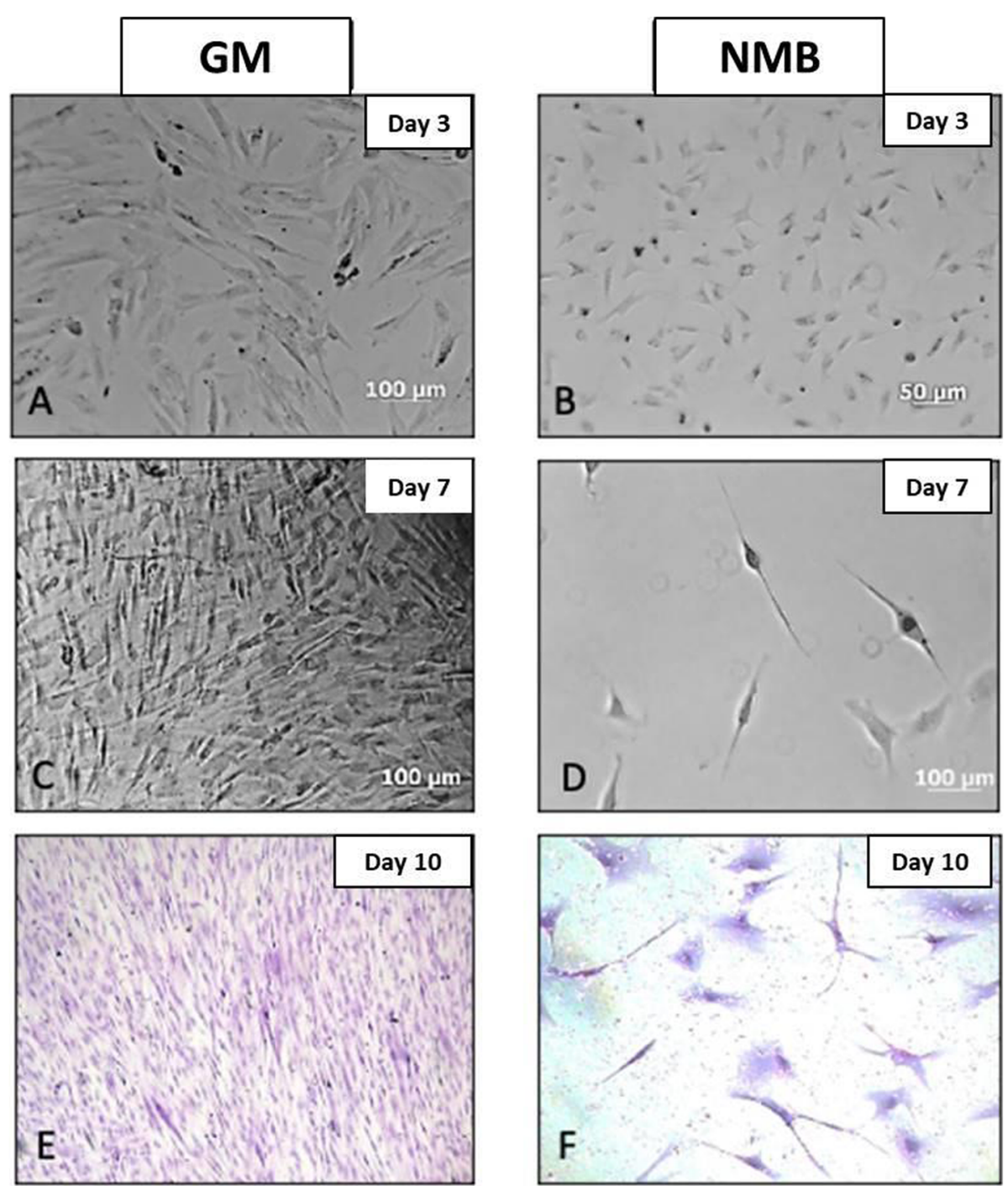

Fig. 5 Neuronal differentiation culture. A Mesenchymal cells in growth medium (GM) at day 3. B Mesenchymal cells from neurospheres in neuronal medium B (NMB) at day 3. C Proliferating mesenchymal cells in GM day 7. D Neuronal cells in the process of morphological differentiation day 7. E Mesenchymal cells with $80 \%$ confluence at day 10. F Neuronal cells differentiated at day 10 in NMB 


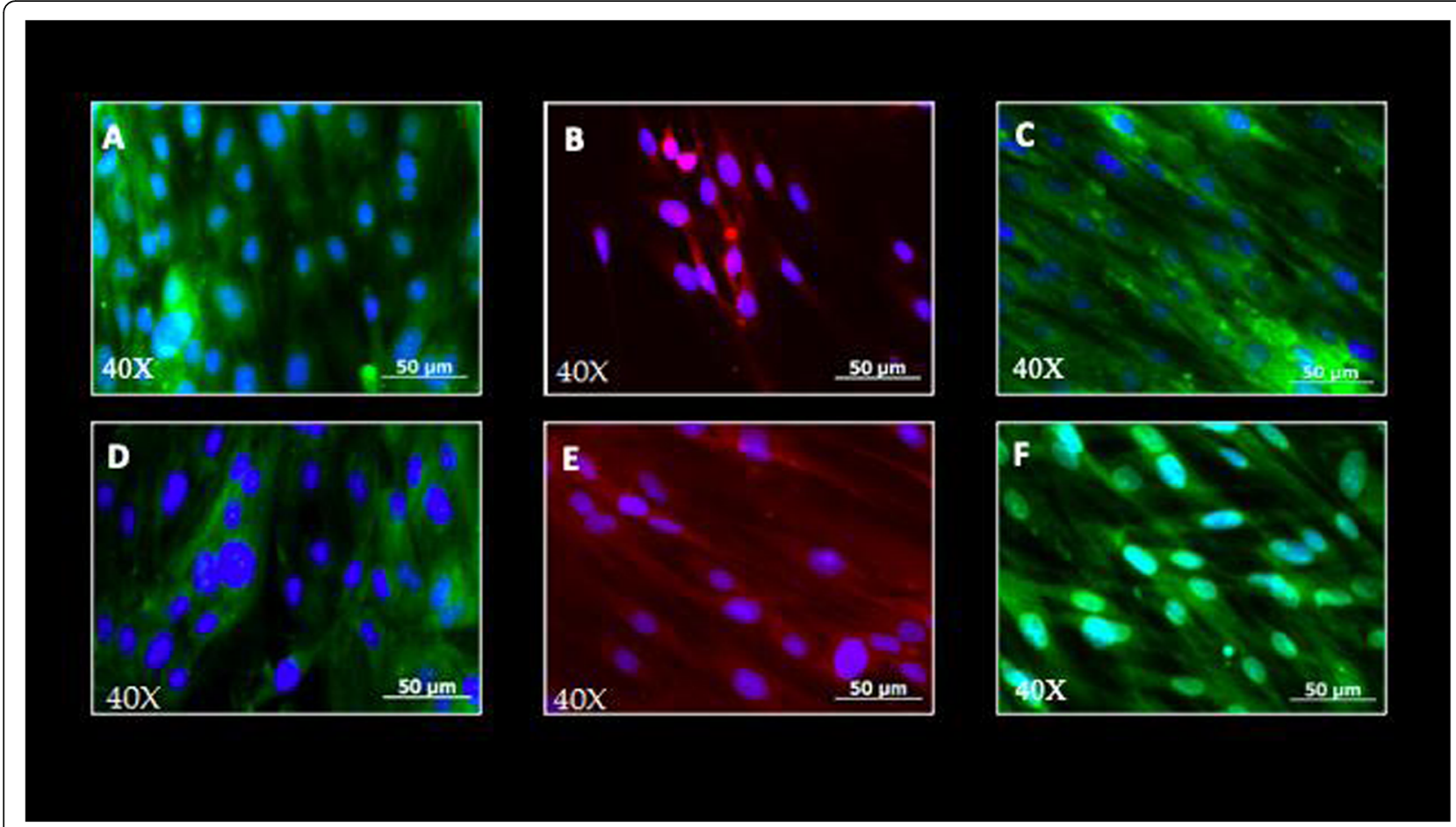

Fig. 6 Immunocytochemistry for identification of mesenchymal cell membrane markers. A CD44 FITC +, (B) CD13 PE +, (C) CD71 FITC +, (D) CD90 FITC +, (E) CD105 PE +, (F) CD146 FITC. Analysis obtained with an inverted fluorescence microscope

In this study, samples were collected from children between 6 and 9 years of age. The samples were teeth from natural exfoliation or indicated for removal for therapeutic reasons; enucleated premolars from 9-year-old children were also included. This study is the first report of research with this type of sample. Others have been documented with dental germs from third molars of adult patients [13].

This study is the first time that magnetic separation with the SSEA-4 antibody in a population of mesenchymal stem cells from human exfoliated deciduous teeth (SHED) is reported. Another study has identified dental pulp stem cells (but not the purification of a cell population with this antibody) by flow cytometry [11]. On the other hand, regarding this cell marker in the embryo stage, it has also been identified as a cell marker in states of neuronal differentiation [14, 15].

SSEA-4 is a specific antigen that can isolate and purify stem cells from human exfoliated deciduous teeth. The obtention of mesenchymal cells by magnetic separation with the SSEA-4 antibody is relevant because this antigen is expressed in embryo pre-implantation stages, embryogenesis, and subsequently, in undifferentiated mesenchymal cells [16]. We can deduce that a cell population that expresses SSEA-4 exists in the dental pulp of deciduous teeth; in the same way, neuroepithelial and neuronal progenitor cells express it during differentiation. These findings allow us to compare the potential of our cell population with naïve cells that present pluripotency $[10,17,18]$.

The SHED obtained by magnetic separation were characterized and identified as a cell population purified from mesenchymal cells, confirmed by immunocytochemistry and flow cytometry, and obtaining positive results for antibodies that correspond to mesenchymal cells and negative for hematopoietic cells antibodies as described by Bianco et al. [19] for the identification of mesenchymal cells. In culture, these cells were dependent on surface adhesion with a spindle shape and organized in highly clonogenic colonies [20,21].

The results of this research provide evidence that supplementation of the SHED culture with the growth factors EGF, FGF, and a low concentration of FBS, leads to the rapid formation of neurospheres from day 3 , compared with other studies that report their formation after 6 days and with treatment carried out with DPSC [22, 23].

It is important to point out that this work was performed with dental pulp from deciduous teeth because children in the early stages of human growth and development have cells with a greater potential for proliferation and differentiation than cells from adults.

The process of neurogenesis in the postnatal period requires multiple steps, such as proliferation, differentiation, migration, cell growth, and synaptic integration. Each of these stages expresses a different marker 

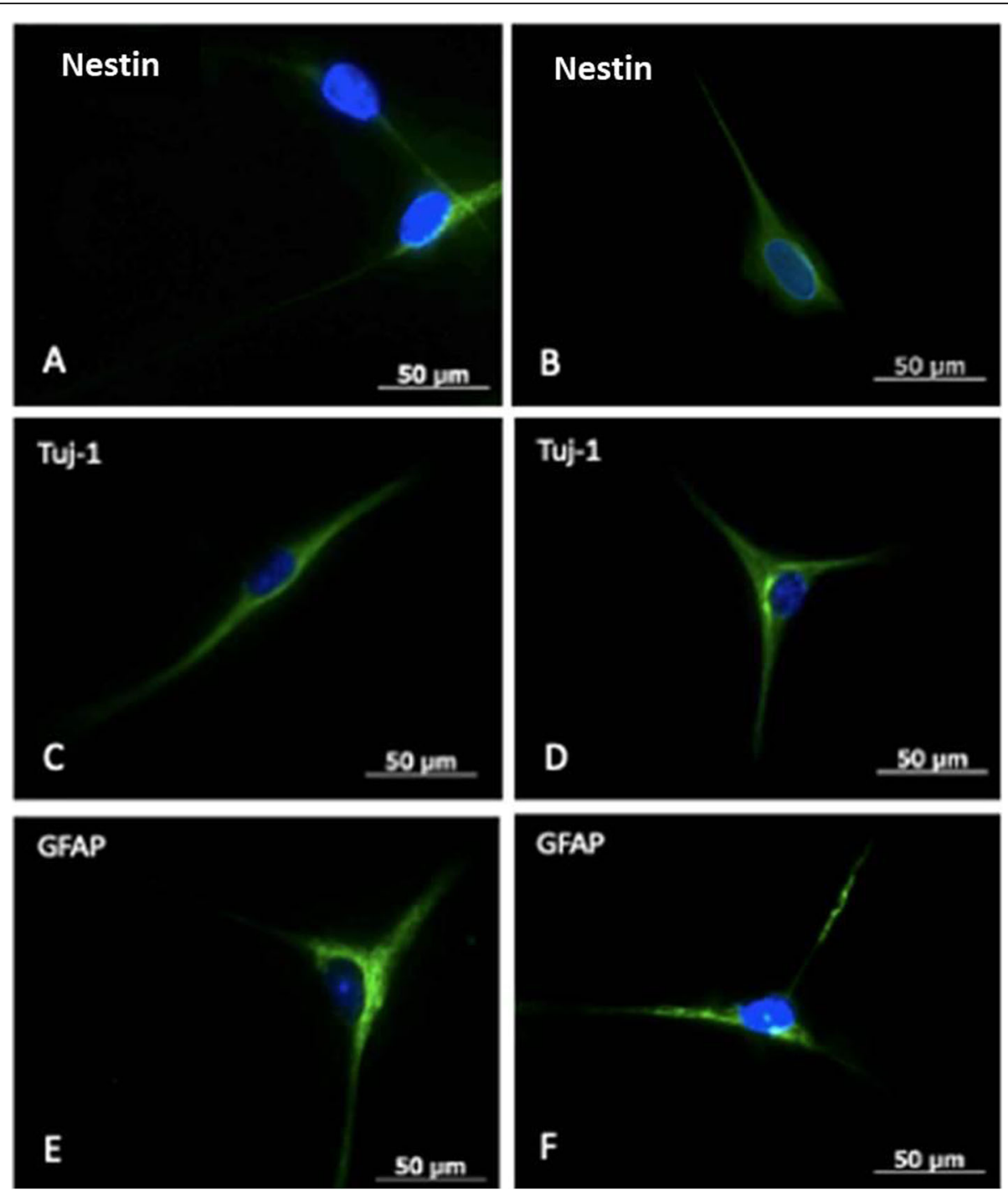

Fig. 7 Immunocytochemistry for identification of neuronal cell membrane markers. A and B Nestin marker positive neuronal cells. C and D Tuj-1 marker positive neuronal cells. $\mathbf{E}$ and $\mathbf{F}$ Glial fibrillar acid protein (GFAP) marker positive neuronal cells. Analysis obtained with an inverted fluorescence microscope

or antigen, such as nestin. In 1990, its expression was identified in most neuronal precursor cells and the morphological development of neuronal and glial cells. Regarding the TuJ-1 marker, it is part of the beta-tubulin family. Its role in mitosis and motility in neuronal cells has been reported with identification in processes such as neurogenesis, development, and axon maintenance. Menezes and Luskin [24] used it for labeling post-mitotic immature neuronal cells. Identification of the GFAP antigen or marker together with nestin has been reported in proliferation states of neuronal precursor cells and alone in stages of glial cell differentiation, particularly astrocytes [3, 25, 26].

With the positive results obtained in our research with immunocytochemistry of the neural markers nestin, TuJ-1, and GFAP, we can state that dental pulp cells from deciduous teeth, treated with neuronal induction, behave like neuronal precursor cells with the ability to mature to neuronal and glial lineages. We can also consider their pluripotent behavior and the ability to originate mesoderm and ectodermderived cell lineages.

Regarding the ethical and therapeutic aspects of stem cells obtained from human embryo tissue and induced pluripotent stem cells, the ethical considerations of dental pulp from deciduous teeth are not controversial because the tissue sample obtained from dental pulp is considered biological waste that causes no harm to life. On the other hand, although induced pluripotent cells have been regarded as superior to those obtained from 
embryo tissue, genomic instability that can form cell tumors in differentiation assays has been identified. This finding has been associated with the reprogramming process; therefore, this cell line is not considered safe for clinical application. Thus, we can consider SHEDs a potential source of cells for inclusion in personalized regenerative medicine therapies $[27,28]$.

Our line of research began in the year 2000, identifying mesenchymal stem cells in human dental pulp [20] that were subsequently identified in primary dentition $[21,29]$. Their ability to differentiate when induced to form bone, cartilage, muscle, and even dentine, has been identified in several studies $[21,30]$. Their ability to differentiate to neuronal lineage, as in the case of neural precursor cells, is one of the newest fields in cell research worldwide. Particularly in Mexico, this line of research in dentistry and its relationship with the neurosciences is being consolidated.

\section{Conclusions}

Our findings on neurodifferentiation show that SSEA4 positive SHEDs have a behavior similar to neuronal precursor cells. Therefore, we can suggest that the human dental pulp of primary teeth is a promising source of MSCs that could be used in regeneration therapies related to neurodegenerative diseases and peripheral nerve disorders.

\section{Acknowledgements}

We thank Sergio Lozano-Rodriguez, M.D. for his help in translating and editing the manuscript.

\section{Authors' contributions \\ Ada Pricila Lopez-Lozano - conception and design of the study; conceived and designed the analysis and the acquisition, analysis, and interpretation of data; drafted the manuscript. Katiushka Arevalo-Niño - Contributed to data acquisition, analysis, and interpretation; critically revised the manuscript for important intellectual content. Yolanda Gutierrez-Puebte - Contributed to data acquisition, analysis, and interpretation; critically revised the intellectual content and reviewed the draft. Jose Luis Montiel-Hernandez - Contributed to data acquisition, analysis, and interpretation; reviewed flow cytometry data, and critically revised the intellectual content. Victor Hugo Urrutia-Baca - critically revised the intellectual content and reviewed the draft. Casiano Del Angel-Mozqueda - Contributed to the conception, data acquisition, analysis, and interpretation, and critically revised the intellectual content. Myriam Angelica De la Garza-Ramos - Contributed to the conception and design of the work; contributed to data acquisition, analysis, and interpretation; participated in drafting the work and critically revised the} intellectual content. The author(s) read and approved the final manuscript.

\section{Funding}

This study received no specific funding from any public, commercial, or notfor-profit agency.

Availability of data and materials

Data are available from the corresponding author upon reasonable request.

\section{Declarations}

Ethics approval and consent to participate

The study was approved by the Ethics Committee of the School of Dentistry of the Autonomous University of Nuevo Leon, registration number SPSI010613/00245.

\section{Consent for publication}

Parents of the pariticpants provided written informed consent for publication.

\section{Competing interests}

The authors declare that they have no competing interests.

\section{Author details}

${ }^{1}$ Facultad de Ciencias Biológicas, Instituto de Biotecnología, Universidad Autónoma de Nuevo León, Nuevo Leon, San Nicolas de los Garza, Mexico. 2Unidad de Odontología Integral y Especialidades, Centro de Investigación y Desarrollo en Ciencias de la Salud, Universidad Autonoma de Nuevo Leon, Nuevo Leon, Monterrey, Mexico. ${ }^{3}$ Facultad De Farmacia, Coordinacion De Posgrado, Universidad Autonoma del Estado de Morelos, Morelos,

Cuernavaca, Mexico. ${ }^{4}$ Facultad de Odontología, Universidad Autonoma de Nuevo Leon, Nuevo Leon, Monterrey, Mexico. ${ }^{5}$ Facultad de Odontología/ CIDICS, Universidad Autonoma de Nuevo Leon Monterrey, San Nicolás de los Garza, Mexico

Received: 9 August 2021 Accepted: 17 February 2022

Published online: 02 March 2022

\section{References}

1. Dibajnia P, Morshead CM. Role of neural precursor cells in promoting repair following stroke. Acta Pharmacol Sin. 2013;34(1):78-90. doi:https://doi.org/1 0.1038/aps.2012.107

2. Reynolds BA, Weiss $\mathrm{S}$. Generation of neurons and astrocytes from isolated cells of the adult mammalian central nervous system. Science. 1992; 255(5052):1707-10. doi:https://doi.org/10.1126/science.1553558.

3. von B und Halbach. O. Immunohistological markers for proliferative events, gliogenesis, and neurogenesis within the adult hippocampus. Cell Tissue Res. 2011;345(1):1-19. doi:https://doi.org/10.1007/s00441-011-1196-4.

4. Ciaramitaro P, Mondelli M, Logullo F, Grimaldi S, Battiston B, Sard A, et al. Traumatic peripheral nerve injuries: epidemiological findings, neuropathic pain and quality of life in 158 patients. J Peripher Nerv Syst. 2010;15(2):1207. doi:https://doi.org/10.1111/j.1529-8027.2010.00260.x.

5. Iohara K, Zheng L, Ito M, Tomokiyo A, Matsushita K, Nakashima M. Side population cells isolated from porcine dental pulp tissue with self-renewal and multipotency for dentinogenesis, chondrogenesis, adipogenesis, and neurogenesis. Stem Cells. 2006;24(11):2493-503. doi:https://doi.org/10.1634/ stemcells.2006-0161.

6. Robey PG, Bianco $P$. The use of adult stem cells in rebuilding the human face. J Am Dent Assoc. 2006;137(7):961-72. doi:https://doi.org/10.14219/ja da.archive.2006.0317

7. Sui B, Wu D, Xiang L, Fu Y, Kou X, Shi S. Dental Pulp Stem Cells: From Discovery to Clinical Application. J Endod. 2020;46(9s):46-s55. doi:https://doi. org/10.1016/j.joen.2020.06.027.

8. Shi X, Mao J, Liu Y. Pulp stem cells derived from human permanent and deciduous teeth: Biological characteristics and therapeutic applications. Stem Cells Transl Med. 2020;9(4):445-64. doi:https://doi.org/10.1002/sctm.190398.

9. Kawanabe N, Fukushima H, Ishihara Y, Yanagita T, Kurosaka H, Yamashiro T. Isolation and characterization of SSEA-4-positive subpopulation of human deciduous dental pulp cells. Clin Oral Investig. 2015;19(2):363-71. doi:https:// doi.org/10.1007/s00784-014-1260-Z.

10. Wang $Y$, Zhao C, Hou Z, Yang Y, Bi Y, Wang H, et al. Unique molecular events during reprogramming of human somatic cells to induced pluripotent stem cells (iPSCs) at naïve state. Elife. 2018;7:e29518. doi:https:// doi.org/10.7554/eLife.29518.

11. Kawanabe N, Murata S, Fukushima H, Ishihara Y, Yanagita T, Yanagita E, et al. Stage-specific embryonic antigen-4 identifies human dental pulp stem cells. Exp Cell Res. 2012;318(5):453-63.

12. Barry FP, Murphy JM. Mesenchymal stem cells: clinical applications and biological characterization. Int J Biochem Cell Biol. 2004;36(4):568-84.

13. Takeda T, Tezuka Y, Horiuchi M, Hosono K, lida K, Hatakeyama D, et al. Characterization of dental pulp stem cells of human tooth germs. J Dent Res. 2008;87(7):676-81.

14. Brøchner CB, Møllgård K. SSEA-4 and YKL-40 positive progenitor subtypes in the subventricular zone of developing human neocortex. Glia. 2016;64(1): 90-104. 
15. Barraud P, Stott S, Møllgård K, Parmar M, Björklund A. In vitro characterization of a human neural progenitor cell coexpressing SSEA4 and CD133. J Neurosci Res. 2007;85(2):250-9.

16. Henderson J, Draper J, Baillie H, Fishel S, Thomson J, Moore H, et al. Preimplantation human embryos and embryonic stem cells show comparable expression of stage-specific embryonic antigens. Stem Cells. 2002;20(4):329-37.

17. Dodsworth $B T$, Flynn $R$, Cowley $S A$. The current state of naive human pluripotency. Stem Cells. 2015;33(11):3181-6.

18. Hanna J, Cheng AW, Saha K, Kim J, Lengner CJ, Soldner F, et al. Human embryonic stem cells with biological and epigenetic characteristics similar to those of mouse ESCs. Proc Natl Acad Sci U S A. 2010;107(20):9222-7. doi: https://doi.org/10.1073/pnas.1004584107.

19. Bianco P, Riminucci M, Gronthos S, Robey PG. Bone marrow stromal stem cells: nature, biology, and potential applications. Stem Cells. 2001;19(3):18092. doi:https://doi.org/10.1634/stemcells.19-3-180.

20. Gronthos S, Mankani M, Brahim J, Robey PG, Shi S. Postnatal human dental pulp stem cells (DPSCs) in vitro and in vivo. Proc Natl Acad Sci U S A. 2000; 97(25):13625-30. doi:https://doi.org/10.1073/pnas.240309797.

21. Miura M, Gronthos S, Zhao M, Lu B, Fisher LW, Robey PG, et al. SHED: stem cells from human exfoliated deciduous teeth. Proc Natl Acad Sci U S A. 2003;100(10):5807-12. doi:https://doi.org/10.1073/pnas.0937635100.

22. Gervois P, Struys T, Hilkens P, Bronckaers A, Ratajczak J, Politis C, et al. Neurogenic maturation of human dental pulp stem cells following neurosphere generation induces morphological and electrophysiological characteristics of functional neurons. Stem Cells Dev. 2015;24(3):296-311. doi:https://doi.org/10.1089/scd.2014.0117.

23. Liu S, Qu Y, Stewart TJ, Howard MJ, Chakrabortty S, Holekamp TF, et al. Embryonic stem cells differentiate into oligodendrocytes and myelinate in culture and after spinal cord transplantation. Proc Natl Acad Sci U S A. 2000; 97(11):6126-31. doi:https://doi.org/10.1073/pnas.97.11.6126.

24. Menezes JR, Luskin MB. Expression of neuron-specific tubulin defines a novel population in the proliferative layers of the developing telencephalon. J Neurosci. 1994;14(9):5399-416. doi:https://doi.org/10.1523/ jneurosci.14-09-05399.1994.

25. Brazel CY, Limke TL, Osborne JK, Miura T, Cai J, Pevny L, et al. Sox2 expression defines a heterogeneous population of neurosphere-forming cells in the adult murine brain. Aging Cell. 2005;4(4):197-207. doi:https://doi. org/10.1111/j.1474-9726.2005.00158.x.

26. Carlén M, Cassidy RM, Brismar H, Smith GA, Enquist LW, Frisén J. Functional integration of adult-born neurons. Curr Biol. 2002;12(7):606-8. doi:https:// doi.org/10.1016/s0960-9822(02)00771-6.

27. Takahashi K, Yamanaka S. Induction of pluripotent stem cells from mouse embryonic and adult fibroblast cultures by defined factors. Cell. 2006;126(4): 663-76. doi:https://doi.org/10.1016/j.cell.2006.07.024.

28. Volarevic V, Markovic BS, Gazdic M, Volarevic A, Jovicic N, Arsenijevic N, et al. Ethical and Safety Issues of Stem Cell-Based Therapy. Int J Med Sci. 2018;15(1):36-45. doi:https://doi.org/10.7150/ijms.21666.

29. Shi S, Gronthos S. Perivascular niche of postnatal mesenchymal stem cells in human bone marrow and dental pulp. J Bone Miner Res. 2003;18(4):696704. doi:https://doi.org/10.1359/jbmr.2003.18.4.696.

30. Jiang W, Ma A, Wang T, Han K, Liu Y, Zhang Y, et al. Homing and differentiation of mesenchymal stem cells delivered intravenously to ischemic myocardium in vivo: a time-series study. Pflugers Arch. 2006;453(1): 43-52. doi:https://doi.org/10.1007/s00424-006-0117-y.

\section{Publisher's Note}

Springer Nature remains neutral with regard to jurisdictional claims in published maps and institutional affiliations.

Ready to submit your research? Choose BMC and benefit from:

- fast, convenient online submission

- thorough peer review by experienced researchers in your field

- rapid publication on acceptance

- support for research data, including large and complex data types

- gold Open Access which fosters wider collaboration and increased citations

- maximum visibility for your research: over $100 \mathrm{M}$ website views per year

At BMC, research is always in progress.

Learn more biomedcentral.com/submissions 